\title{
PERLINDUNGAN HUKUM TERHADAP PEREMPUAN BERHADAPAN DENGAN HUKUM SEBELUM DAN SESUDAH LAHIRNYA PERATURAN MAHKAMAH AGUNG NOMOR 3 TAHUN 2017 TENTANG PEDOMAN MENGADILI PERKARA PEREMPUAN BERHADAPAN DENGAN HUKUM
}

\author{
Nurhilmiyah \\ Fakultas Hukum Universitas Muhammadiyah Sumatera Utara \\ Jl. Kapten Muchtar Basri No. 3, Medan - Sumatera Utara \\ Email: nurhilmiyah@umsu.ac.id
}

\begin{abstract}
Abstrak
Masalah perlindungan terhadap perempuan masih menarik untuk diteliti. Aturan perundangundangan yang ada sejauh ini harus terus memastikan implementasinya dengan baik dan benar. Setiap orang adalah sama sebelum hukum dan perundang-undangan melarang diskriminasi dan menjamin perlindungan yang sama bagi setiap orang dari diskriminasi berdasarkan alasan apa pun, termasuk gender. Menjadi menarik ketika Mahkamah Agung Indonesia mengeluarkan Perma No. 3 tahun 2017 dari pedoman untuk menuntut masalah perempuan dengan hukum. Penulis ingin menemukan jawaban atas pertanyaan tersebut, bagaimana tepatnya perlindungan negara terhadap perempuan yang bertentangan dengan hukum sebelum dan sesudah penerbitan Perma No. 3 tahun 2017.
\end{abstract}

\section{Kata Kunci: Perlindungan, Hukum, Perempuan, Berkonflik}

\section{Abstract}

The problem of protection against women is still interesting to research. The rules of legislation that exist so far must continue to ensure its implementation properly and properly. Everyone is the same before laws and legislation prohibits discrimination and guarantees equal protection for everyone from discrimination based on any reason, including gender. It became interesting when the Supreme Court of Indonesia issued a Perma No. 3 year 2017 of the guidelines to prosecute women's issues with the law. The author wants to find answers to the question, how exactly is the legal protection state of women who are conflicted with the law before and after the issuance of Perma No. 3 year 2017.

Keywords: Protection, Law, Women, Conflict, Supreme Court Law

\section{PENDAHULUAN}

Perkembangan ilmu dan teknologi di segala bidang saat ini, telah melahirkan perubahan kultur budaya umat manusia yang beraneka ragam. Akibatnya, hukum materiil dengan segala aspeknya mengalami perkembangan keunikan, dan keanekaragaman. Dalam tataran seperti ini, hukum acara yang kodratnya selalu mengabdi kepada hukum materiil, seharusnya mengikuti sifat perkembangan, keunikan dan keanekaragaman hukum materiil untuk menjaga keseimbangan keadilan hukum yang dipikul oleh Surat Edaran Mahkamah Agung (SEMA) dan Peraturan Mahkamah Agung (PERMA) (Ahmad Kamil dan Fauzan, 2008, h. 6).

Di dalam konteks ini, kedudukan SEMA dan PERMA dalam praktik hukum acara di Indonesia memiliki peran yang urgen bagi hakim di seluruh Indonesia. Sebagai pembaruan 
Jurnal Ilmu Hukum

FAKULTAS HUKUM UMSU
Perlindungan Hukum Terhadap...(Nurhilmiyah)

Volume 4 Nomor 2, Juli-Desember 2019, 211-219 DOI: https://doi.org/10.30596/dll.v4i2.3172

pedoman untuk menjalankan tugas pokok peradilan. SEMA dan PERMA memiliki sifat kepekaan terhadap implikasi hukum yang dirasa tidak adil, tidak kondusif, dan tidak responsif terhadap fenomena hukum yang berkembang. Celah-celah hukum acara yang dinilai lemah dan berakibat mudah disalahgunakan oleh oknum dan public, terasa mendesak untuk diatasi dengan melahirkan yurisprudensi, atau mengeluarkan SEMA dan PERMA. Kedua lembaga ini sangat efektif dan cepat untuk mengantisipasi mengisi kekosongan atau celah hukum tersebut. Argumentasi lainnya, bahwa ternyata SEMA dan PERMA ini jarang sampai atau sekurangkurangnya terlambat sampai di kalangan kampus. Akibatnya kajian hukum acara sebagai ilmu sering kurang mengikuti perkembangan hukum acara dalam praktiknya di pengadilan. Dosen dan mahasiswa jarang mengetahui pembaruan hukum acara yang ada pada SEMA dan PERMA.

Perlindungan terhadap warga negara dari segala tindakan diskriminasi merupakan implementasi dari hak konstitusional sebagaimana tertuang dalam Undang-Undang Dasar Negara Republik Indonesia Tahun 1945. Indonesia telah meratifikasi Kovenan Internasional tentang Hak-Hak Sipil dan Politik (International Covenant on Civil and Political Right/ICCPR) dengan Undang-Undang Nomor 12 Tahun 2005 tentang Pengesahan International Covenant on Civil and Political Rights (Kovenan Internasional tentang Hak-Hak Sipil dan Politik) yang menegaskan bahwa semua orang adalah sama di hadapan hukum dan peraturan perundangundangan melarang diskriminasi serta menjamin perlindungan yang setara bagi semua orang dari diskriminasi berdasarkan alasan apapun, termasuk jenis kelamin atau gender (Perma Nomor 3 Tahun 2017 tentang Pedoman Mengadili Perkara Perempuan Berhadapan dengan Hukum).

Sebagai negara pihak dalam Konvensi Penghapusan Segala Bentuk Diskriminasi Terhadap Perempuan (Convention on the Elimination of All Forms of Discrimination Against Women/CEDAW) Indonesia mengakui kewajiban negara untuk memastikan bahwa perempuan memiliki akses terhadap keadilan dan bebas dari diskriminasi dalam sistem peradilan (Melalui, https://www.hukum-hukum.com/2018/01/perempuan-yang-berhadapan-dengan-hukum.html)

Berdasarkan pertimbangan peraturan perundang-undangan yang telah terlebih dahulu ada, maka Mahkamah Agung perlu menetapkan Peraturan Mahkamah Agung tentang Pedoman Mengadili Perkara Perempuan Berhadapan dengan Hukum. Tentunya menjadi sebuah pertanyaan, bagaimana perlindungan hukum terhadap perempuan berhadapan dengan hukum sebelum dan sesudah lahirnya Perma Nomor 3 Tahun 2017 tentang Pedoman Mengadili Perkara Perempuan Berhadapan dengan Hukum.

\section{METODE PENELITIAN}

Pendekatan (approach) yang digunakan dalam penelitian ini adalah pendekatan yuridis normatif. Menurut Sutarto, (Nico Ngani, 2012, h. 178-179), pendekatan, selain merupakan terjemahan dari kata approach (bahasa Inggris), pendekatan juga disebut aliran sebagai terjemahan dari kata school. HB. Sutopo di buku yang sama menggunakan istilah perspektif. Jika digiring ke ranah semantik, kata semantik, kata perspektif sinonim dengan sudut pandang (point of view) atau titik tolak. 
Jurnal Ilmu Hukum

FAKULTAS HUKUM UMSU
Perlindungan Hukum Terhadap...(Nurhilmiyah)

Volume 4 Nomor 2, Juli-Desember 2019, 211-219 DOI: https://doi.org/10.30596/dll.v4i2.3172

Berdasarkan pemikiran tersebut di atas, maka kita dapat memahami kebiasaankebiasaan yang muncul dalam suatu penelitian. Termasuk di dalamnya pendekatan yuridis normatif. Atas dasar pendekatan ini, maka bahan utama yang akan ditelaah adalah bahan hukum primer, bahan hukum sekunder, dan bahan hukum tersier. Sebagai konsekuensi dari pendekatan (approach, school, perspektif) di atas, maka dalam suatu penelitian terdapat dua metode yang dapat dibedakan tetapi tak terpisahkan, masing-masingnya diikuti dengan metode sintesis (kesimpulan).

Penelitian yuridis normatif membahas doktrin-doktrin atau asas-asas dalam ilmu hukum. Selain asas-asas yang jelas termuat di dalam Pasal 5 dan 6 Undang-Undang Nomor 12 Tahun 2011 tentang Pembentukan Peraturan Perundang-Undangan, peraturan perundang-undangan tertentu dapat berisi asas lain sesuai dengan bidang hukum peraturan perundang-undangan yang bersangkutan. Sebagai contoh doktrin itikad baik, doktrin fakta hukum, dan sebagainya. Penelitian ini kerap disebut penelitian yang bersifat teoretis. Saat ini penelitian kategori ini sangat langka atau kurang diminati oleh para akademisi (Zainuddin Ali, 2013, h. 24-25).

Jenis penelitian yang digunakan dalam penulisan ini adalah penelitian pustaka (library research). Library research berarti penelitian yang menggunakan dokumen tertulis sebagai data, dan sumber data yang digunakan dalam penelitian ini mencakup bahan hukum primer dan bahan hukum sekunder. Bahan hukum primer adalah bahan hukum yang mengikat atau yang membuat orang taat hukum, meliputi produk hukum yang menjadi bahan kajian dan produk hukum sebagai alat kritiknya. Bahan hukum sekunder meliputi penjelasan bahan hukum primer berupa doktrin para ahli yang ditemukan dalam buku, jurnal, dan website (Rahmat Ramadhani, 2017, h. 142).

Merujuk pada pendekatan-pendekatan tersebut, penulis menggunakan pendekatan perundang-undangan (statute approach), pendekatan konseptual (conceptual approach), pendekatan sejarah (hystorical approach), dan pendekatan filosofis (philosophical approach). Pendekatan perundang-undangan digunakan untuk melihat permasalahan kepastian hukum mengenai perlindungan hukum terhadap perempuan berkonflik dengan hukum dalam Undang Undang Dasar Negara Republik Indonesia (UUD) 1945 dan Undang-Undang Nomor 31 Tahun 2014 tentang Perubahan atas Undang-Undang Nomor 13 Tahun 2006 tentang Perlindungan Saksi dan Korban.

Pendekatan konseptual digunakan untuk melihat konsepsi perlindungan hukum terhadap perempuan yang berkonflik dengan hukum. Sedangkan pendekatan sejarah digunakan dengan melihat sejarah lahirnya Perma Nomor 3 Tahun 2017 di Indonesia. Pendekatan filosofis digunakan untuk melihat makna esensial perlindungan hukum terhadap perempuan berkonflik dengan hukum melalui pendekatan-pendekatan tersebut. Maka perkembangan pemaknaan perlindungan perempuan berkonflik dengan hukum dianalisis secara deskriptif kualitatif agar dapat sampai pada kesimpulan akhir yang akan menjawab semua pokok permasalahan dalam penelitian.

Setelah data dikumpulkan, kegiatan selanjutnya adalah melakukan analisis. Analisis yang digunakan dalam penelitian ini adalah analisis yuridis normatif kualitatif deskriptif, 
Jurnal Ilmu Hukum

FAKULTAS HUKUM UMSU
Perlindungan Hukum Terhadap...(Nurhilmiyah)

Volume 4 Nomor 2, Juli-Desember 2019, 211-219

DOI: https://doi.org/10.30596/dll.v4i2.3172

dinamakan analisis karena pekerjaan yang dilakukan oleh peneliti adalah menguraikan bahan yang dikumpulkannya secara rinci berdasarkan kriteria tertentu. Untuk bahan yang bentuknya peraturan perundang-undangan maka menurut Gustav Radbruch, (Nico Ngani, 2012, h. 181), rinciannya adalah bagaimana struktur, konstruksi dan interpretasi peraturan itu.

\section{PEMBAHASAN}

\section{Perlindungan Hukum Terhadap Perempuan Berhadapan Dengan Hukum Sebelum Lahirnya PERMA Nomor 3 Tahun 2017 tentang Pedoman Mengadili Perkara Perempuan Berhadapan dengan Hukum}

Menurut Pasal 1 PERMA Nomor 3 Tahun 2017 tentang Pedoman Mengadili Perkara Perempuan Berhadapan dengan Hukum, perempuan berhadapan dengan hukum adalah perempuan yang berkonflik dengan hukum. Ada 3 (tiga) pihak perempuan yang berkonflik dengan hukum tersebut:

a. Perempuan sebagai korban

b. Perempuan sebagai saksi

c. Perempuan sebagai pihak

Pasal 2 PERMA Nomor 3 Tahun 2017 tentang Pedoman Mengadili Perkara Perempuan Berhadapan dengan Hukum memuat asas yang mestinya ditaati hakim dalam mengadili perkara perempuan berhadapan dengan hukum. Asas-asas tersebut adalah, asas penghargaan atas harkat dan martabat manusia; asas non diskriminasi; asas kesetaraan gender; asas persamaan di depan hukum; asas keadilan; asas kemanfaatan; dan asas kepastian hukum.

Berdasarkan penelitian sebelumnya yang dilakukan oleh Bella Sandiata (2018) dalam Jurnal Perempuan yang berjudul Perempuan Berhadapan dengan Hukum: Refleksi Penggunaan Pasal 284 dan 285 KUHP dalam Pengalaman Pendamping Hukum, pendamping sendiri berarti seseorang atau kelompok atau organisasi yang dipercaya dan/atau memiliki keterampilan dan pengetahuan untuk mendampingi perempuan berhadapan dengan hukum, dengan tujuan membuat perempuan merasa aman dan nyaman dalam memberikan keterangan selama proses peradilan berlangsung.

Hasil penelitian di atas menunjukkan bahwa hukum di Indonesia masih tidak berpihak kepada perempuan korban. Keadilan bagi para perempuan korban masih jauh panggang dari api karena posisi perempuan korban yang masih kerap dilemahkan oleh (aparat penegak) hukum. Reformasi sistem hukum secara tertulis dan hukum acara diperlukan untuk mengakomodasi pengalaman perempuan korban. Sistem dan produk tersebut harus dapat memastikan suatu peraturan perundang-undangan, termasuk hukum pidana, yang berperspektif gender dan berpihak pada perempuan korban. Prinsip--prinsip dalam teori hukum feminis merupakan suatu solusi untuk menghentikan praktik hukum yang bias gender, salah satunya adalah dengan berupaya untuk mendengar pengalaman perempuan korban.

Lebih jauh lagi, perubahan perspektif akibat budaya patriarki yang menyubordinasikan perempuan perlu dilakukan dalam tiga unsur sistem hukum secara menyeluruh yakni struktur hukum, substansi hukum, dan budaya hukum. Reformasi hukum ke depan juga perlu melihat dan melibatkan (pengalaman) perempuan sehingga keadilan bagi perempuan korban yang 
Jurnal Ilmu Hukum FAKULTAS HUKUM UMSU
Perlindungan Hukum Terhadap...(Nurhilmiyah)

Volume 4 Nomor 2, Juli-Desember 2019, 211-219 DOI: https://doi.org/10.30596/dll.v4i2.3172

berhadapan dengan perkara hukum bukan menjadi hal utopis dan sungguh dapat memberikan jawaban atas pencarian keadilan oleh para perempuan korban yang telah berani melaporkan segala bentuk ketidakadilan yang dialaminya (Sandiata: 2018).

Relevansinya dengan Undang-Undang Perlindungan Saksi dan Korban, perlindungan dan penghargaan terhadap saksi atau korban atau pelapor merupakan suatu prinsip yang telah diatur dalam Undang-Undang Nomor 13 Tahun 2006 tentang Perlindungan Saksi dan Korban, Undang-Undang Nomor 30 Tahun 2002 tentang Komisi Pemberantasan Tindak Pidana Korupsi dan Undang-Undang Nomor 8 Tahun 2010 tentang Pencegahan dan Pemberantasan Tindak Pidana Pencucian Uang karena berkaitan dengan pentingnya keterangan saksi atau korban dalam mengungkapkan fakta hukum atas tindak pidana korupsi, tindak piudana pencucian uang, tindak pidana narkotika/psikotropika, tindak pidana terorisme, dan tindak pidana lain yang mengakibatkan posisi saksi dan korban dihadapkan pada situasi yang sangat membahayakan.

Perlindungan saksi atau korban atau pelapor penting diberikan karena menyangkut ancaman atau intimidasi yang diterima oleh saksi atau korban atau pelapor atas keterangan atau laporan untuk mengungkapkan kejahatan tersebut. Mekanisme Perlindungan saksi dan korban telah diterapkan melalui sistem pelaporan dan perlindungan yang ada di Lembaga Perlindungan Saksi atau Korban (LPSK), Komisi Pemberantasan Korupsi (KPK) dan Pusat Pelaporan Analisis Transaksi Keuangan (PPATK). Upaya perlindungan saksi atau korban tidak hanya diatur dalam Undang-Undang Nomor 13 Tahun 2006 tentang Perlindungan Saksi dan Korban, Undang-Undang Nomor 30 Tahun 2002 tentang Komisi Pemberantasan Tindak Pidana Korupsi, dan Undang-Undang Nomor 8 Tahun 2010 tentang Pencegahan dan Pemberantasan Tindak Pidana Pencucian Uang tetapi juga perlu diatur dalam KUHAP, sebagai ketentuan beracara dalam proses peradilan pidana.

Mekanisme perlindungan saksi atau korban atau pelapor perlu mempertimbangkan sistem perlindungan yang terintegrasi untuk meningkatkan efektivitas dan efisiensi penanganan tindak pidana yang serius seperti korupsi, tindak pidana pencucian, narkotika, HAM berat dan lainnya. Serta perlu meningkatkan jaminan kerahasiaan saksi atau korban atau pelapor terhadap tindak pidana serius tersebut. (Wangga: 2013).

Menurut Institute for Criminal Justice Reform (ICJR) pada praktiknya, sebelum lahirnya PERMA Nomor 3 Tahun 2017 tentang Pedoman Mengadili Perkara Perempuan Berhadapan dengan Hukum ini terdapat inkonsistensi persepsi hakim terkait dengan proses peradilan yang melibatkan perempuan. Ditemui beberapa putusan hakim yang memberikan pertimbanganpertimbangan yang justru menjauhkan perempuan untuk mendapatkan akses keadilan. Sebagai contoh dalam perkara kasus pencabulan dengan nomor perkara 1391/Pib.B/PA/2007/PN.LP hakim justru memberikan pertimbangan yang tidak relevan dengan menjabarkan perbuatanperbuatan korban yang dinilainya melanggar ketertiban umum, seperti riwayat seksual korban. Hal ini membuat korban semakin sulit memperoleh keadilan (ICJR: 2017).

Belum lagi permasalahan perbedaan pandangan antarhakim dalam memutus hukuman bagi pelaku kekerasan terhadap perempuan dalam hal terdapat relasi kuasa. Relasi kuasa menurut PERMA Nomor 3 Tahun 2017 tentang Pedoman Mengadili Perkara Perempuan 
Jurnal Ilmu Hukum

FAKULTAS HUKUM UMSU
Perlindungan Hukum Terhadap...(Nurhilmiyah)

Volume 4 Nomor 2, Juli-Desember 2019, 211-219 DOI: https://doi.org/10.30596/dll.v4i2.3172

Berhadapan dengan Hukum adalah relasi yang bersifat hierarkis, ketidaksetaraan dan/atau ketergantungan status sosial, budaya, pengetahuan/pendidikan, dan /atau ekonomi yang menimbulkan kekuasaan pada satu pihak terhadap pihak lainnya dalam konteks relasi antargender sehingga merugikan pihak yang memiliki posisi lebih rendah.

Putusan Nomor 106/Pid.Sus/2011/PN.SKH dan Putusan Nomor 410/Pid.B/2014/PN. Bg1 menunjukkan ketimpangan relasi kuasa tersebut. Dalam putusan pertama, majelis hakim melihat relasi kuasa sebagai hal yang dapat meringankan hukuman pelaku. Hakim mempertimbangkan janji menikahi korban sebagai dasar memperingan hukuman. Sedangkan dalam putusan kedua, relasi kuasa ditafsirkan hakim secara progresif sebagai unsur paksaan dalam tindak pidana perkosaan. Dari kedua putusan tersebut terlihat secara jelas tidak adanya pedoman yang jelas bagi hakim untuk memeriksa perkara yang berkaitan dengan adanya ketimpangan gender antara pelaku dengan korban dalam konteksi ini, perempuan.

Kehadiran PERMA Nomor 3 Tahun 2017 tentang Pedoman Mengadili Perkara Perempuan Berhadapan dengan Hukum ini dinilai cukup akomodatif dalam memberikan definisi relasi kuasa itu sendiri. Memberikan pedoman bagi hakim untuk mengkaji relasi kuasa pada saat mengadili perkara yang melibatkan perempuan. Selain itu adanya PERMA Nomor 3 Tahun 2017 tentang Pedoman Mengadili Perkara Perempuan Berhadapan dengan Hukum ini juga dapat dijadikan momentum yang baik bagi lahirnya putusan-putusan yang progresif dalam hal mengakomodasi hak-hak korban, khususnya perempuan serta mengantisipasi penafsiran rumusan-rumusan tindak pidana yang justru merugikan korban.

Di dalam proses penanganan perkara ditemukan semacam stereotip perlakuan yang diskriminatif. Misalnya korban perkosaan seringkali diperiksa oleh hakim dan penegak hukum lainnya mengenai riwayat seksual (masih perawan atau tidak), pakaian apa yang dikenakan, termasuk menanyakan gaya apa yang dilakukan oleh pelaku saat memperkosa korban (Hukum Online, 2019).

Adanya Pasal 5 PERMA Nomor 3 Tahun 2017 tentang Pedoman Mengadili Perkara Perempuan Berhadapan dengan Hukum, secara tegas memuat bahwa Dalam pemeriksaan perempuan berhadapan dengan hukum, hakim tidak boleh:

a. Menunjukkan sikap atau mengeluarkan pernyataan yang merendahkan, menyalahkan dan/atau mengintimidasi perempuan berhadapan dengan hukum

b. Membenarkan terjadinya diskriminasi terhadap perempuan dengan menggunakan kebudayaan, aturan adat, dan praktik tradisional lainnya maupun menggunakan penafsiran ahli yang bias gender

c. Mempertanyakan dan/atau mempertimbangkan mengenai pengalaman atau latar belakang seksualitas korban sebagai dasar untuk membebaskan pelaku atau meringankan hukuman pelaku, dan

d. Mengeluarkan pernyataan atau pandangan yang mengandung stereotip gender.

Sterotip gender menurut PERMA Nomor 3 Tahun 2017 tentang Pedoman Mengadili Perkara Perempuan Berhadapan dengan Hukum adalah pandangan umum atau kesan tentang atribut atau karakteristik yang seharusnya dimiliki dan diperankan perempuan atau laki-laki. 
DEIEGA LATA

Jurnal Ilmu Hukum

FAKULTAS HUKUM UMSU
Perlindungan Hukum Terhadap...(Nurhilmiyah)

Volume 4 Nomor 2, Juli-Desember 2019, 211-219

DOI: https://doi.org/10.30596/dll.v4i2.3172

\section{Perlindungan Hukum Terhadap Perempuan Berhadapan Dengan Hukum Sesudah Lahirnya Perma Nomor 3 Tahun 2017}

Berdasarkan penelusuran penulis mengenai proses penanganan perkara pada perkara pidana, pada perkara perdata juga ditemukan perbedaan kondisi penegakan hukum pasca lahirnya PERMA Nomor 3 Tahun 2017 tentang Pedoman Mengadili Perkara Perempuan Berhadapan dengan Hukum. Dalam hal ini mengenai perkara cerai talak (ct) dan cerai gugat (cg) pada peradilan agama.

Sebelum adanya PERMA Nomor 3 Tahun 2017 tentang Pedoman Mengadili Perkara Perempuan Berhadapan dengan Hukum, pada cerai talak tidak ada amar yang memerintahkan kepada Pemohon untuk melaksanakan putusan yakni membayar beban sebelum ikrar talak diucapkan. Dalam pertimbangan hukum hakim terdapat adanya perintah pembayaran nafkah iddah dan mut'ah yang dibayarkan sebelum pengucapan ikrar talak akan tetapi kurang maksimal.

Setelah adanya PERMA Nomor 3 Tahun 2017 tentang Pedoman Mengadili Perkara Perempuan Berhadapan dengan Hukum, bekas suami boleh membayar iddah dan mut'ah sebelum atau sesudah pengucapan ikrar talak. Pada praktiknya, bekas suami diperintahkan untuk membayar iddah dan mut'ah sebelum pengucapan ikrar talak putusan. Tentunya hal ini suatu terobosan yang sangat menarik untuk dikaji. Sebab belum diketemukan dalam kaidah hukum Islam dan hukum positif bahwa bekas suami diwajibkan membayar iddah dan mut'ah sebelum pengucapan ikrar talak.

Pada perkara cerai gugat, sebelum adanya PERMA Nomor 3 Tahun 2017 tentang Pedoman Mengadili Perkara Perempuan Berhadapan dengan Hukum, bekas istri tidak mendapatkan hak-haknya atau nafkah, mut'ah, iddah dan nafkah madliyah. Sesudah dikeluarkannya PERMA Nomor 3 Tahun 2017 tentang Pedoman Mengadili Perkara Perempuan Berhadapan dengan Hukum, pada putusan gugatan perceraian Nomor 3529/Pdt.G/2017/PA.Kdr, istri juga tidak memperoleh hak-haknya tersebut. Berdasarkan wawancara dengan hakim Pengadilan Agama Kab. Kediri, Syamsurijal, menjelaskan bahwa alasan hakim tidak memberikan hak-hak istri berupa nafkah iddah dan mut'ah, karena pada putusan cerai gugata, pihak istri yang mengajukan gugatan perceraian sehingga dalam hal ini istri dianggap nusyuz sehingga tidak berhak mendapatkan hak-hak nafkah iddahnya (Rikza: 2018).

Menurut penulis, belum tentu istri yang mengajukan gugatan perceraian bisa dianggap nusyuz (melawan perintah suami/durhaka/membangkang). Sebab berdasarkan data yang diperoleh dari Kepaniteraan Pengadilan Agama Medan, faktor penyebab nomor satu istri melayangkan cerai gugat adalah faktor ekonomi. Spesifiknya suami tidak menjalankan tanggung jawab menafkahi istri dan anaknya. Faktor kedua adalah adanya campur tangan pihak ketiga dalam rumah tangga para pihak, disusul faktor selanjutnya ketiadaan komitmen para pihak untuk menjaga kelangsungan pernikahannya.

Sesuai dengan asas penghargaan atas harkat dan martabat perempuan sebagai seorang manusia, asas keadilan dan kemanfaatan yang terkandung di dalam PERMA Nomor 3 Tahun 

FAKULTAS HUKUM UMSU
Perlindungan Hukum Terhadap...(Nurhilmiyah)

2017 tentang Pedoman Mengadili Perkara Perempuan Berhadapan dengan Hukum, seyogyanya hakim mampu melakukan penafsiran peraturan perundang-undangan dan/atau hukum tidak tertulis yang dapat menjamin kesetaraan gender terkait pemenuhan hak-hak penghidupan yang layak bagi pihak istri yang mengajukan cerai gugat. Sebagaimana Pasal 6 PERMA Nomor 3 Tahun 2017 tentang Pedoman Mengadili Perkara Perempuan Berhadapan dengan Hukum ini hakim diharapkan mampu menggali nilai-nilai hukum, kearifan lokal dan rasa keadilan yang hidup dalam masyarakat guna menjamin kesetaraan gender, perlindungan yang setara, non diskriminasi.

\section{KESIMPULAN DAN SARAN \\ Kesimpulan}

Perlindungan hukum terhadap perempuan berhadapan dengan hukum sebelum lahirnya PERMA Nomor 3 Tahun 2017 tentang Pedoman Mengadili Perkara Perempuan Berhadapan dengan Hukum, masih dijumpai penanganan perkara dan putusan peradilan yang justru menimbulkan ketidakadilan terhadap perempuan. Perlindungan hukum terhadap perempuan berhadapan dengan hukum setelah lahirnya PERMA Nomor 3 Tahun 2017 tentang Pedoman Mengadili Perkara Perempuan Berhadapan dengan Hukum diharapkan semakin baik sebab pasal-pasal yang ada di PERMA Nomor 3 Tahun 2017 tentang Pedoman Mengadili Perkara Perempuan Berhadapan dengan Hukum tersebut telah mengatur proses penanganan perkara yang berkeadilan gender.

\section{Saran}

Pentingnya tindak lanjut dari lahirnya PERMA Nomor 3 Tahun 2017 tentang Pedoman Mengadili Perkara Perempuan Berhadapan dengan Hukum dengan sosialisasi secara lebih meluas dan komprehensif serta berkelanjutan. Agar PERMA ini lebih implementatif guna meminimalisasi penanganan perkara oleh hakim yang tidak sensitif gender. Sehingga kehadiran PERMA ini tidak sekadar lip service bagi upaya perlindungan hukum terhadap perempuan. 
Jurnal Ilmu Hukum

FAKULTAS HUKUM UMSU
Perlindungan Hukum Terhadap...(Nurhilmiyah)

Volume 4 Nomor 2, Juli-Desember 2019, 211-219

DOI: https://doi.org/10.30596/dll.v4i2.3172

\section{DAFTAR PUSTAKA}

Ali, Zainuddin. (2013). Metode Penelitian Hukum. Jakarta: Sinar Grafika.

Dabie. (2019). Urgensi Terbitnya Perma Pedoman Mengadili Perkara Perempuan. Diakses $\begin{array}{lllll}\text { pada } & \text { tanggal } & 12 & \text { Mei } & 2019\end{array}$ https://www.hukumonline.com/berita/baca/lt598af94b94acd/penting-urgensi-terbitnyaperma-pedoman-mengadili-perkara-perempuan.

E, Maria Sylvia., \& Wangga. (2013). Perlindungan Saksi dan Korban. Jurnal Legislasi. Volume 10. Nomor 1. Maret.

Institute for Criminal Justice Reform. (2017). Diakses pada tanggal 20 Meo 2019 melalui https://icjr.or.id/icjr-mengapresiasi-terbentuknya-peraturan-mahkamah-agung-tentangpedoman-mengadili-perkara-perempuan-berhadapan-dengan-hukum/

Kamil, Ahmad., \& Fauzan, M. (2008). Ke Arah Pembaruan Hukum Acara Perdata Dalam SEMA Dan PERMA. Jakarta: Kencana Prenada Media Group.

Nico, Ngani. (2012). Metodologi Penelitian Dan Penulisan Hukum. Yogyakarta: Pustaka Yustisia.

Peraturan Mahkamah Agung Nomor 3 Tahun 2017 tentang Pedoman Mengadili Perkara Perempuan Berhadapan Dengan Hukum.

Ramadhani, Rahmat. (2017). Jaminan Kepastian Hukum Yang Terkandung Dalam Sertipikat Hak Atas Tanah. Jurnal De Lega Lata, Volume 2, Nomor 1, Juli.

Rikza, Naufal. (2019). Pengaruh Perma No. 3 Tahun 2017 Terhadap Perkara Perceraian Di Pengadilan Agama (Tinjauan Putusan Perceraian di Pengadilan Agama Kabupaten Kediri). Diakses pada tanggal 15 Mei 2019 melalui http://eprints.ums.ac.id/63435/10/7.\%20NASKAH\%20PUBLIKASI.pdf.

Sandiata, Bella. (2018). Refleksi Penggunaan Pasal 284 dan 285 KUHP dalam Pengalaman Pendamping Hukum. Jurnal Perempuan, Volume 23, Nomor 2, Mei.

Undang-Undang No. 31 Tahun 2014 tentang Perubahan atas Undang-Undang No. 13 Tahun 2006 tentang Perlindungan Saksi dan Korban.

Undang-Undang Nomor 35 Tahun 2014 tentang Perubahan Atas Undang-Undang Nomor 23 Tahun 2002 tentang Perlindungan Anak. 